\title{
Accelerators as authentic learning experiences for nascent entrepreneurs
}

\author{
Morgan P. Miles \\ University of Canterbury \\ New Zealand \\ Morgan.miles@canterbury.ac.nz \\ Huibert de Vries \\ University of Canterbury \\ New Zealand \\ herb.devries@ canterbury.ac.nz \\ Geoff Harrison \\ Victoria University \\ New Zealand \\ Geoff.Harrison@vuw.ac.nz \\ Martin Bliemel \\ University of New South Wales \\ mbliemel@unsw.edu.au \\ Saskia de Klerk \\ University of New South Wales \\ Australia \\ $\underline{\text { S.DeKlerk@adfa.edu.au }}$ \\ Chickery J. Kasouf \\ Worcester Polytechnic Institute \\ USA \\ chick@wpi.edu
}

Cite as:

Morgan P. Miles, Huibert de Vries, Geoff Harrison, Martin Bliemel, Saskia de Klerk, Chick J. Kasouf, (2017) "Accelerators as authentic training experiences for nascent entrepreneurs", Education + Training, Vol. 59 Issue: 7/8, pp.811-824, https://doi.org/10.1108/ET-01-2017$\underline{0007}$ 


\begin{abstract}
Purpose - The purpose of this paper is to address the role of accelerators as authentic learning-based entrepreneurial training programs. Accelerators facilitate the development and assessment of entrepreneurial competencies in nascent entrepreneurs through the process of creating a start-up venture.
\end{abstract}

Design/methodology/approach - Survey data from applicants and participants of four startaccelerators are used to explore the linkages between accelerators and the elements of authentic learning. Authentic learning processes are then mapped onto the start-up processes that occur within the accelerators.

Findings - Accelerators take in nascent entrepreneurs and work to create start-ups. This activity develops the participants' entrepreneurial competencies and facilitates authentic selfreflection.

Research limitations/implications - This study explores how accelerators can be useful as authentic learning platforms for the development of entrepreneurial competencies. Limitations include perceptual measures and the inability to conduct paired sampling.

Practical implications - Entrepreneurship training is studied through the lens of authentic learning activities that occur within an accelerator. Participants develop and assess their mastery of and interest in entrepreneurship through tasks, exposure to experts and mentors, peer learning, and assessments such as pitching to investors at Demo Day.

Originality/value - This paper reports on the authentic learning processes and its usefulness in competency development and self-appraisal by accelerators participants. The opportunity for competency development and self-appraisal by nascent entrepreneurs before escalating their commitment to a start-up may be an accelerator's raison d'être.

Keywords Experiential learning, Entrepreneurial competencies, Authentic learning, Accelerators, Entrepreneurship education and training, Self-appraisal

Paper type Conceptual paper 
People tend to hold overly favorable views of their abilities in many social and intellectual domains. The authors suggest that this overestimation occurs, in part, because people who are unskilled in these domains suffer a dual burden: Not only do these people reach erroneous conclusions and make unfortunate choices, but their incompetence robs them of the metacognitive ability to realize it. (Kruger and Dunning, 1999, p. 1121)

\section{Introduction}

Entrepreneurship has recently become a more popular career option. For example, Fayolle et al. (2016, p. 896) citing the 2016 Global Entrepreneurship Monitor survey notes "that $66 \%$ of adults consider entrepreneurship to be a very good career choice and half believe that they have the capacity to engage in entrepreneurial activity." Similarly, Amway's Global Entrepreneurship Report found $77 \%$ of participants hold a positive attitude towards self-employment, and $43 \%$ perceive that they can successfully start a business (Amway, 2016). However, in entrepreneurship as in any other activity when confidence exceeds competencies, both pecuniary and non-pecuniary losses may result (Kruger and Dunning, 1999; Hayward et al., 2006).

Entrepreneurial competencies can be developed through entrepreneurship education and training $(E E \& T)$ programs that actively engage learners in the creation and assessment of their competencies (Matlay, 2001, 2006; Jones and Matlay, 2011; Balan and Metcalfe, 2012; Jones et al., 2014; Robinson et al., 2016). This can be accomplished by employing authentic learning techniques in EE\&T programs (Leppisaari et al., 2013; Lackéus and Middleton, 2015; Bliemel, 2016; Lahn and Erikson, 2016; Macht and Ball 2016; Scott et al., 2016).

Accelerators are being recognized for their ability to create realistic learning experiences (Graham, 2012; Cohen, 2013; Bliemel et al., 2016; Hallen et al., 2016); and have even been touted as the "new business school" for entrepreneurs (Miller and Bound, 2011; 
The Economist, 2014; TechCrunch, 2015; Gonzalez-Uribe and Leatherbee, 2016).

Accelerators do this by providing a realistic learning experience that bridges education and practice (Lackéus and Middleton, 2015).

This paper explores the role of accelerators as an authentic learning based EE\&T program. Authentic EE\&T learning requires context and activities that mimic the experience of entrepreneurs, thereby aligning entrepreneurial learning with practice (e.g. Herrington and Oliver, 2000; Lackéus and Middleton, 2015; Macht and Ball, 2016). This study of four startup accelerators (1) links the process occurring within accelerators to Herrington and Oliver's (2000) authentic learning framework; (2) explores how accelerators' activities facilitate the development of entrepreneurial capabilities; and (3) proposes accelerators are effective EE\&T programs that provide entrepreneurs the opportunity to assess and reflect on their competencies and career interests through an intense short-term immersion in the practice of entrepreneurship.

\section{Entrepreneurial competencies}

Entrepreneurship is opportunity-seeking behavior (Stevenson and Gumpert, 1985) that requires different competencies than management, specifically the ability to recognize and assess opportunities (Morris et al., 2013). Competencies pertaining to opportunity recognition and assessment are widely recognized as essential for entrepreneurship to occur (Venkataraman, 1997; Shane and Venkataraman, 2000; Ardichvili et al., 2003; Kirzner, 2009; Davidsson, 2015). Lans et al. (2011, p. 697) define entrepreneurial competencies as the "identification and development of opportunities aiming towards new ventures, innovation, or strategic renewal." Morris et al. (2013) suggest that entrepreneurial 
competencies include the ability to discover, assess, and exploit value-creating opportunities through leveraging resources, social networks, and innovation.

The ability of the entrepreneur to create and renew products, processes, strategies, organizations and markets rests on being able to perceive, assess and exploit economic opportunities (Shane and Venkataraman, 2000). These competencies are important across a variety of disciplines including agriculture, business, engineering, and science (Maritz and Brown, 2013; Kyndt and Baert, 2015; Mehlhorn et al., 2015; Thongpravati et al., 2016).

\section{Authentic learning and accelerators}

Entrepreneurship is largely action based (Klein, 2008; Garud et al., 2014). As such, EE\&T is a pedagogical domain that makes it well suited to experiential learning (e.g. Kolb, 1984; Breuer and Mahdjour, 2012; Bergmann and Sams, 2014). Thus, many EE\&T initiatives employ experiential learning exercises (Balan et al., 2015; Kassean et al., 2015; Piperopoulos and Dimov, 2015; Scott et al., 2016). Authentic learning is an emerging area of experiential learning with specific components, including realism of the environment, exercises, assessment, and learning (Macht and Ball, 2016). These components combine in the context of an accelerator to amplify the development of entrepreneurial competencies.

Authentic learning mimics the experience of the entrepreneur. For example, Herrington and Oliver (2000, p. 23) note that:

[...] much of the abstract knowledge taught in schools and universities is not retrievable in real-life, problem solving contexts, because [the conventional] approach ignores the interdependence of situation and cognition. When learning and context are separated, knowledge itself is seen by learners as the final product of education rather than a tool to be used dynamically to solve problems. 
Herrington and Oliver's (2000) framework of authentic learning, summarized in

Table 1, articulates nine elements that are used in accelerators to bridge the gap between nascent entrepreneurs knowing about entrepreneurship and successfully practicing entrepreneurship. The first two elements of authentic learning immerse learners in a realistic situation and provide context-specific tasks that require the application of the learning competencies. The next two elements employ competency experts, such as role models to demonstrate the application of the competencies and then offer multiple perspectives on the efficacy and efficiency of the competency on the targeted task. Peer-to-peer learning and reflective self-appraisal provides valuable feedback to the learners. The last three elements include participants articulating their understanding of the competencies, coaches developing and mentoring the participants on their specific competency gaps, and a comprehensive opportunity assessment. Table 1 summarizes how these processes can be implemented within accelerators.

Table 1

Elements of authentic learning and corresponding implementation in accelerators

\begin{tabular}{|l|l|}
\hline Elements of authentic learning & Implementation guidelines \\
\hline $\begin{array}{l}\text { Situate learners in an authentic } \\
\text { context }\end{array}$ & $\begin{array}{l}\text { Accelerators are located in situ co-working spaces } \\
\text { and a community entrepreneurial ecosystem }\end{array}$ \\
\hline $\begin{array}{l}\text { Engage learners in authentic tasks } \\
\text { and activities }\end{array}$ & $\begin{array}{l}\text { Learners are faced with the realistic task of } \\
\text { developing an actual start-up using lean methods }\end{array}$ \\
\hline $\begin{array}{l}\text { Use role models to demonstrate } \\
\text { expert performance of the task and } \\
\text { activities }\end{array}$ & $\begin{array}{l}\text { Accelerator educational programs and entrepreneurial } \\
\text { ecosystem events such as pitch nights highlight } \\
\text { expert entrepreneurs employing entrepreneurial } \\
\text { competencies }\end{array}$ \\
\hline $\begin{array}{l}\text { Expose learners to multiple and } \\
\text { diverse perspectives }\end{array}$ & $\begin{array}{l}\text { Accelerator educational programs, entrepreneurial } \\
\text { ecosystem events, and the mentors offer exposure to } \\
\text { diverse and multiple perspectives }\end{array}$ \\
\hline $\begin{array}{l}\text { Facilitate learner peer-to-peer } \\
\text { collaboration }\end{array}$ & $\begin{array}{l}\text { Contact through co-working spaces, internal pitching } \\
\text { events within the accelerator, and networking events } \\
\text { facilitate peer-to-peer collaboration and often expose }\end{array}$ \\
\hline
\end{tabular}




\begin{tabular}{|l|l|}
\hline & the learners to new opportunities \\
\hline $\begin{array}{l}\text { Create opportunities for learner } \\
\text { reflection, peer- and self-appraisal }\end{array}$ & $\begin{array}{l}\text { Internal pitching events and discussions with } \\
\text { accelerator managers, mentors, and experts presenting } \\
\text { in educational programs offer reflective appraisal } \\
\text { opportunities }\end{array}$ \\
\hline $\begin{array}{l}\text { Provide opportunities for learners } \\
\text { to articulate competencies }\end{array}$ & $\begin{array}{l}\text { Internal pitching events and discussions with } \\
\text { accelerator managers, mentors, and experts presenting } \\
\text { in educational programs force learners to articulate } \\
\text { their learnings }\end{array}$ \\
\hline $\begin{array}{l}\text { Engage coaching, mentoring and } \\
\text { scaffolding }\end{array}$ & $\begin{array}{l}\text { Formal on-line educational programs such as Steve } \\
\text { Blank's "How to build a start-up" course on udacity } \\
\text { (www.udacity.com). }\end{array}$ \\
$\begin{array}{l}\text { Formal expert lectures and presentations used very } \\
\text { early in the accelerator program. } \\
\text { Informal mentoring replacing formal teaching over } \\
\text { the course of the accelerator }\end{array}$ \\
\hline Make all assessment authentic & $\begin{array}{l}\text { Realistic informal and formal assessment occur } \\
\text { throughout the accelerator program - with the most } \\
\text { authentic assessment at the end - the pitch at Demo- } \\
\text { Day to solicit follow-on equity investments }\end{array}$ \\
\hline
\end{tabular}

1: Herrington and Oliver (2000)

2: Herrington and Parker (2013)

3: Bliemel et al. (2016)

\section{A model of accelerators as authentic learning program}

All accelerators have the purpose of building entrepreneurial competencies, and they do this by providing "limited duration entrepreneurship education programs that accelerate learning during venture gestation" reinforced by peer-to-peer and mentor-based learning experiences (Cohen and Bingham, 2013, p. 14803). The operating processes of accelerators have largely converged on a typical three to four-month program based on the work of organizations such as the Global Accelerator Network (www.gan.co) and the Case Foundation (www.casefoundation.org). For example, all four accelerators studied employed a three-month start-up program based on 
1. A competitive selection process for selecting a cohort of ten three-person teams.

2. Mentors and workshop/seminar leaders serve as vocational coaches and trainers.

3. Incorporation of lean start-up processes.

4. Early-stage equity funding support.

5. A series of educational (like business angel forums) and assessment events (like the Demo-Day graduation where the start-ups pitch their business to venture investors in a an open community event).

6. A full-time commitment by participants.

Typically, the program is scheduled as follows, during the first month teams move into a shared co-working space, meet with a range of mentors with diverse perspectives and experiences, learn and practice lean processes, such as business model validation and customer development, and attend workshops, seminars and entrepreneurial ecosystem networking events (Christiansen, 2009; Bliemel et al., 2016; Hathaway, 2016). Mentors, including entrepreneurial founders and executives, meet with the teams to reinforce learning, challenge assumptions and guide them on the realities of start-ups. In addition, the teams often pivot to different business models during the first month of the accelerator due to discussions with potential customers, suppliers, and mentors. In the second month, teams develop the business model and begin to test it with real customer feedback on their minimum viable product (MVP). The teams also seek evidence of how the well their MVPs solve customer problems to assess commercial viability and scalability.

Month three, is largely devoted to refining the business proposition and developing the presentation for a formal pitch that seeks follow-on equity investments by business angels, venture investors and other stakeholders at the Demo-Day event. In addition, during the last month of the accelerator educational training focuses on developing an understanding of what is required for each team to become attractive to equity investors at the Demo-Day 
event. Figure 1 summarizes the accelerator process as a 3-month EE\&T authentic learning program (e.g. Herrington and Oliver, 2000).

\section{Figure 1}

\section{The authentic educational dimensions of start-up accelerator ${ }^{1}$}

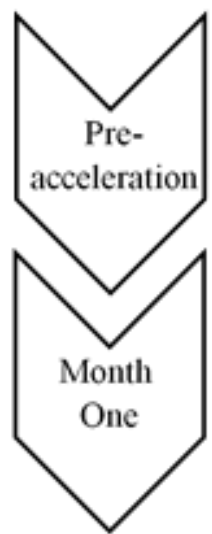

Authentic Context

- Competitive application process asking entrepreneursto present themselves \& their venture idea in the best possible light

\section{Access to Expert Performances \& Multiple Perspectives + Authentic Activities}

- Receive seed funding

- Move into accelerator \& meet other teams, staff and mentors

- Educational seminars

- Mentor and staff coaching towards

- Business model development

- Develop an initial minimum viable product (MVP)

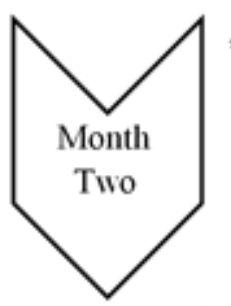

Authentic Articulation + Coaching + Collaborative Learning

- Peer learning through accountability meetings

- Out-of-the-building engagement to

- Validate business model and MVP

- Gain evidence of customer \& supply chain buy-in

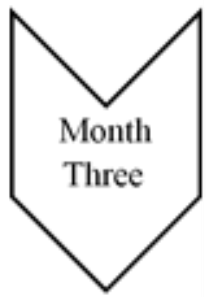

Authentic Assessment \& Reflection

- Peer learning through accountability meetings

- Out-of-the-building engagement to

- Validate business model \& MVP

- Gain evidence of customer \& supply chain buy-in

- Demo Day

\section{1: Source: $\underline{w w w . c a s e f o u n d a t i o n . o r g ; ~} \underline{\text { ww.lightninglab.co.nz }}$}

Authentic EE\&T blurs which actions are part of education and which parts are practice (e.g., Lackéus and Middleton, 2015). It also expands the scope of EE\&T programs beyond learning to include commercial outcomes such as venture creation and economic development through the creation of jobs and tax revenues (e.g., Matlay, 2001, 2006). All 
nine elements of authentic learning are found within the start-up processes of accelerators that immerse and situate the participants in the context of entrepreneurship practice. The accelerator process requires the teams of nascent entrepreneurs to learn how to recognize and assess economic opportunities, activities that are critical entrepreneurial competencies. Likewise, the limited timeframe of the accelerator forces the teams into a high-pressure situation, a realistic context faced by entrepreneurs. Accelerators develop and assess entrepreneurial competencies in nascent entrepreneurs and offer a context to explore EE\&T options that include experiential-based programs using coaching and mentoring (e.g. Pauwels et al., 2016; Roberts et al., 2016). Miller and Bound (2011, p. 33) found in a series of interviews with venture investors, academics, entrepreneurs, and accelerator managers in Europe and the U.S. that accelerators are already perceived as start-up schools due to the “[...] accelerated pace of learning and real life experience that accelerators provide compared to business schools [...]."

In the accelerators, outside experts provide seminars and serve as role models demonstrating the expert performance of authentic tasks and become mentors to the nascent entrepreneurs, while offering multiple perspectives on many issues facing start-ups. Likewise, co-location and the expectation of full-time commitment to the accelerator by the nascent entrepreneurs creates both a competitive and cooperative learning environment where there is learner peer-to-peer collaboration sometimes driven by the work culture of the accelerator. For example, Hathaway (2016, p. 4) notes that

what is it about what accelerators do that makes them so different from other early stage investors and support organizations and so valuable to the start-ups $[\ldots]$ that they are apparently falling over each other to be in their ranks? I recently posed this question to Brad Feld, a co-founder of TechStars, and he likened the accelerator experience to immersive education, where a period of 
intense, focused attention provides company founder an opportunity to learn at a rapid pace.

Accelerators also offer multiple and authentic opportunities for peer and self-appraisal through both the informal day-to-day work within the accelerator and formal events such as pitch nights. Cohen (2013) and Hallen et al. (2016, p. 1) conclude that "intense learning" is one of the immediate outcomes of accelerators. Accelerators purposefully scaffold participant-learning processes throughout the program by supplementing formal educational curricula with intensive mentoring and coaching (Wood et al., 1976). For example, in the first month participants meet frequently and intensively with a broad assortment of mentors curated by the accelerator's management team. In months two and three accelerators support participant learning with coaching from accelerator managers, mentor specialists, and industry experts. The requirement for all teams to "pitch" their start-up as an investment opportunity to business angels and other venture investors at the accelerator's Demo-Day is an authentic assessment, with real investors, investing real money, and very real economic consequences. This Demo-Day pitch experience and the amount of follow-on venture investments that the start-ups receive is one of the main performance metrics accelerators boards use to judge the accelerator's effectiveness (e.g. Miller and Bound, 2011; Bliemel et al., 2016).

The activities employed within the accelerator are what occurs in practice, and participants have the opportunity to reflect and appraise their perceived mastery of entrepreneurial competencies in an authentic context and through authentic assessments. Reflection in experience is a "critical aspect of an authentic learning environment" (Herrington et al., 2014, p. 24). Reflection by participants on their experiences after 
immersion in the accelerator may result in a more realistic self-perception of their level of attainment of core entrepreneurial competencies such as opportunity recognition and assessment.

The outcome of an accelerator experience may result in one of three conclusions by the nascent entrepreneur: (1) they are confidently pursue the start-up; (2) they perceive the need to develop a deeper mastery of entrepreneurial competencies but continue the start-up; or (3) they realize that the start-up is not a good option and they abort. The ability of the accelerator to provide an authentic appraisal of the nascent entrepreneur's competencies and continued interest in pursuing the start-up is illustrated in Figure 2. This process offers the nascent entrepreneur a realistic glimpse of what an entrepreneurial career involves and the competencies required to succeed. While for some, it may reinforce their decision to pursue an entrepreneurial career, for others abandoning their intentions to start a venture may be a desirable outcome that ameliorates potential future pecuniary and non-pecuniary losses (Shane, 2009). 


\section{Figure 2}

Accelerators and authentic learning, reflection, and the start-up decision ${ }^{1}$

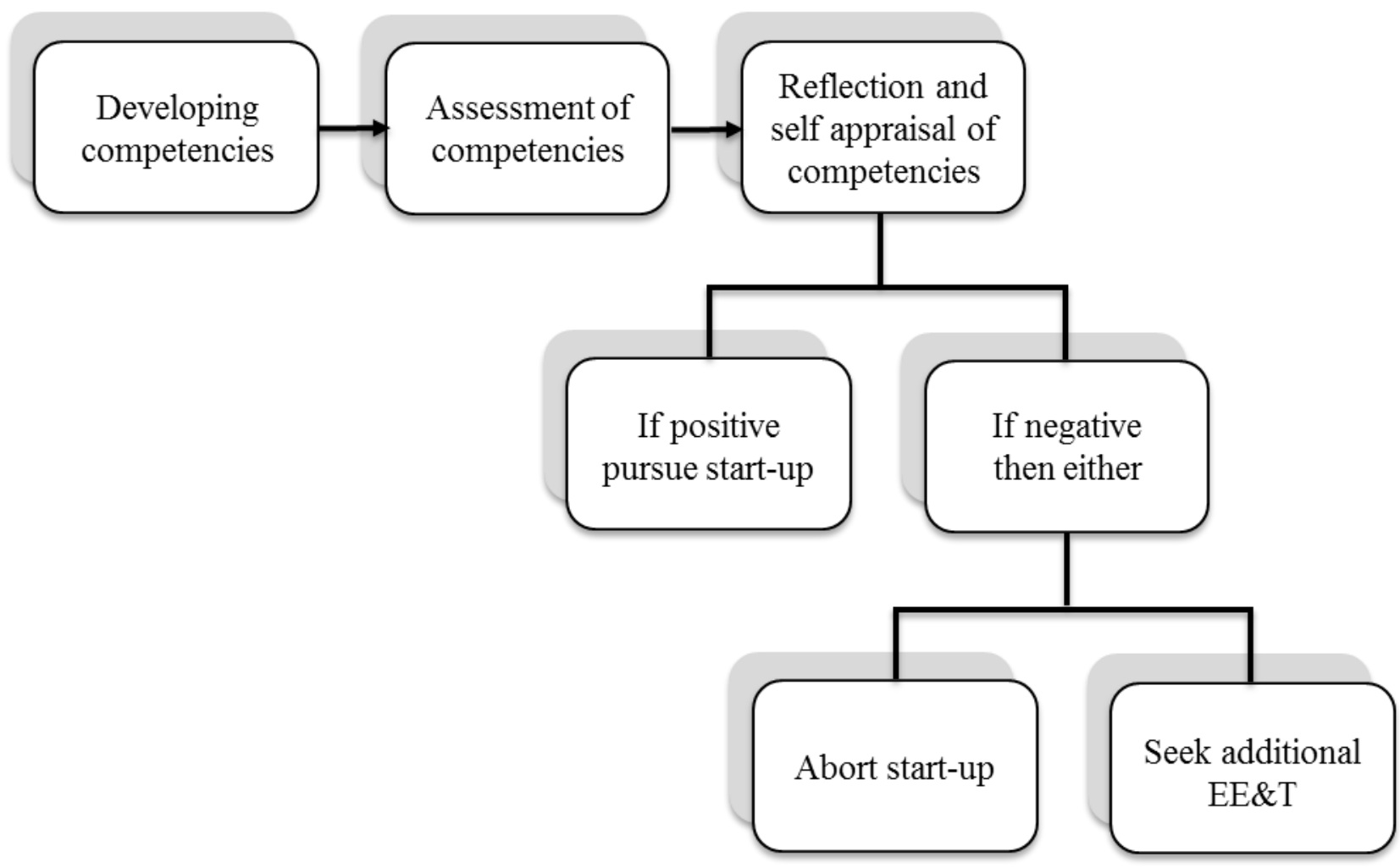

1: Adapted from Herrington et al. (2014)

\section{Methods}

The paper uses data gathered from a short survey of accelerator applicants and participants. During October of 2015, the directors of four New Zealand based accelerators were asked if they would request that their accelerator applicants for their 2016 programs participate in a brief on-line survey. The survey included Morris et al.'s (2013) six-item scale measuring respondents' perceived competency in recognizing opportunities and Morris et al.'s (2013) three-item scale measuring respondents' perceived competency in assessing opportunities. A pre/post survey design was employed. For confidentially, the accelerator managers controlled the administration of the on-line survey. This procedural step did not 
allow for the assessment of response rates, non-response bias, or the use of a paired sampling design.

Accelerator applicants completed seventy-seven usable surveys prior to participation in the accelerator programs. After completion of the accelerator programs, the participants were surveyed again. Accelerator managers again facilitated the survey process and sent participants reminder emails. In total, thirty-two usable post accelerator surveys were collected. Due to the request of accelerator managers and the small number of responses from the individual accelerators, the data from all four accelerators were aggregated into two groups: (1) pre-acceleration, and (2) post-acceleration, thus excluding the opportunity for paired or matched sample testing.

To test if the perceived level of entrepreneurial competencies became more realistic due to participation in the accelerator one-tailed independent sample t-tests were used to assess if the mean of the post-acceleration sample was less than the mean of the preacceleration sample for the opportunity recognition and opportunity assessment scales.

\section{Findings}

To test for common method bias, Harmon's one-factor test was used. If all variables load on a single unrotated factor, there is evidence of common methods bias (Podsakoff and Organ, 1986; Sardeshmukh and Corbett, 2011). Morris et al.'s (2013) six items that purport to measure opportunity recognition and three items that purport to measure opportunity assessment were factor analyzed using principle components without rotation procedures (Podsakoff and Organ, 1986; Sardeshmukh and Corbett, 2011). Three factors emerged from the nine items suggesting that common methods bias in not imposing artificial co-variation and therefore not a material issue in the present study (Table 2). 
Table 2

Harmon's one-factor test of Common Method Bias

Component Matrix ${ }^{\mathrm{a}}$

\begin{tabular}{|l|l|l|l|}
\hline \multirow{2}{*}{} & \multicolumn{3}{|c|}{ Component } \\
\cline { 2 - 4 } & 1 & 2 & 3 \\
\hline $\begin{array}{l}\text { I am an avid information seeker. } \\
\text { I am always actively looking for new }\end{array}$ & .464 & .663 & .485 \\
information. & .555 & .619 & .424 \\
$\begin{array}{l}\text { I often make novel connections and perceive } \\
\text { new or emergent relationships between various } \\
\text { pieces of information. }\end{array}$ & .827 & .136 & -.312 \\
$\begin{array}{l}\text { I see links between seemingly unrelated pieces } \\
\text { of information. }\end{array}$ & .734 & .166 & -.462 \\
$\begin{array}{l}\text { I am good at "connecting the dots." } \\
\text { I often see connections between previously } \\
\text { unconnected domains of information. } \\
\text { I can distinguish between profitable } \\
\text { opportunities and not so profitable } \\
\text { opportunities. }\end{array}$ & .790 & -.017 & -.288 \\
I have a knack for telling high-value \\
opportunities apart from low-value \\
$\begin{array}{l}\text { opportunities. } \\
\text { When facing multiple opportunities, I am able } \\
\text { to select the good ones. }\end{array}$ & .626 & -.027 & -.390 \\
\hline
\end{tabular}

Extraction Method: Principal Component Analysis.

a. 3 components extracted.

The six-item opportunity recognition scale exhibited a Cronbach's Alpha coefficient of .85 compared to a range of Cronbach Alphas reported by Morris et al. (2013) that ranged from .79 to .87 . The three-item opportunity assessment scale exhibited a Cronbach's Alpha coefficient of .84 compared to the Cronbach Alpha coefficient of .84 reported by Morris et al. (2013). The two scales exceeded Nunnally's (1978) criteria of .70, suggesting adequate reliability. 
The mean of the pre-acceleration sample for opportunity recognition was 4.16 and rose to 4.27 in the post-acceleration sample (Tables 3, 5). The pre-acceleration sample mean for opportunity assessment was 3.79 , which declined to 3.51 in the post-acceleration sample, but was not statistically significant (Tables 4,5$)$.

Table 3

Entrepreneurship Competencies perceived to be possessed by 2016 NZ Accelerator Participants: Opportunity Recognition ${ }^{1}$

\begin{tabular}{|l|l|l|l|}
\hline & Mean & Std. Deviation & N \\
\hline $\begin{array}{l}\text { I am an avid information seeker. } \\
\text { I am always actively looking for new } \\
\text { information. }\end{array}$ & 4.3462 & .66492 & 104 \\
$\begin{array}{l}\text { I often make novel connections and perceive } \\
\text { new or emergent relationships between various } \\
\text { pieces of information. }\end{array}$ & 4.1346 & .71132 & 104 \\
$\begin{array}{l}\text { I see links between seemingly unrelated pieces } \\
\text { of information. }\end{array}$ & 4.1442 & .79340 & 104 \\
$\begin{array}{l}\text { I am good at "connecting the dots." } \\
\text { I often see connections between previously } \\
\text { unconnected domains of information. }\end{array}$ & 4.0192 & .81229 & 104 \\
\hline
\end{tabular}

1: Morris et al.'s (2013) 
Table 4

Entrepreneurship Competencies perceived to be possessed by 2016 NZ Accelerator Participants: Opportunity Assessment ${ }^{1}$

\section{Item Statistics}

\begin{tabular}{|l|l|l|l|}
\hline & Mean & Std. Deviation & N \\
\hline $\begin{array}{l}\text { I can distinguish between profitable } \\
\text { opportunities and not so profitable } \\
\text { opportunities. }\end{array}$ & 3.7170 & .84802 & 106 \\
$\begin{array}{l}\text { I have a knack for telling high-value } \\
\text { opportunities apart from low-value } \\
\text { opportunities. } \\
\begin{array}{l}\text { When facing multiple opportunities, I am able } \\
\text { to select the good ones. }\end{array}\end{array}$ & 3.6321 & .94944 & 106 \\
\hline
\end{tabular}

1: Morris et al.'s (2013)

Table 5

T-test - Independent samples

\begin{tabular}{|ll|l|l|l|l|}
\hline & $\begin{array}{l}\text { GROUP (1 Pre, 2 } \\
\text { Post) }\end{array}$ & $\mathrm{N}$ & Mean & Std. Deviation & $\begin{array}{l}\text { Std. Error } \\
\text { Mean }\end{array}$ \\
\hline OppRec & PRE & 73 & 4.1575 & .50985 & .05967 \\
& POST & 31 & 4.2742 & .61546 & .11054 \\
\hline OppAsses & PRE & 74 & 3.7883 & .73730 & .08571 \\
& POST & 32 & 3.5104 & .74768 & .13217 \\
\hline
\end{tabular}

\begin{tabular}{|c|c|c|c|c|}
\hline & & $T$ & Df & Sig. (1-tailed) \\
\hline OppRec & $\begin{array}{l}\text { Equal variances } \\
\text { assumed } \\
\text { Equal variances not } \\
\quad \text { assumed }\end{array}$ & $\begin{array}{l}-1.002 \\
-.929\end{array}$ & $\begin{array}{l}102 \\
48.323\end{array}$ & $\begin{array}{l}.1595 \\
.179\end{array}$ \\
\hline OppAsses & $\begin{array}{l}\text { Equal variances } \\
\text { assumed } \\
\text { Equal variances not } \\
\text { assumed }\end{array}$ & $\begin{array}{l}1.774 \\
1.764\end{array}$ & $\begin{array}{l}104 \\
58.184\end{array}$ & $\begin{array}{l}.0395 \\
.0415\end{array}$ \\
\hline
\end{tabular}




\section{Preliminary insights}

The most important insight from this study is that accelerators can facilitate learning of entrepreneurship through the start-up experience. While accelerators are often created to develop start-ups and bolster entrepreneurial ecosystems (Bliemel et al., 2016), they appear to be effective EE\&T authentic learning programs that use the experiences of creating a startup to develop entrepreneurial competencies and self-awareness in nascent entrepreneurs.

Whether by design or circumstance, self-confident nascent entrepreneurs lacking in entrepreneurial competency are particularly well suited to participation in accelerators (e.g. Kasouf et al., 2015). Accelerator participants may be inexperienced in both business and entrepreneurship, but are often motivated by the desire to (1) be a founder; (2) create income and wealth; (3) solve a social, business, or consumer problem; or (4) commercialize an innovation (Miller and Bound, 2011; Bliemel et al., 2016; Kanbach and Stubner, 2016). However, motivation coupled with overconfidence and hubris can result in negative outcomes without the appraisal and reflection feedback opportunity that an accelerator provides its participants (e.g. Hayward et al., 2006; Hogarth and Karelaia, 2012; Nambisan and Baron, 2013).

Figure 3 relates entrepreneurial competencies to self-efficacy, as developed by Kasouf et al. (2015) and adapted further by Miles et al. (2016). In the U.S.'s National Science Foundation's I-Corp (www.nsf.gov/publications/pubumm.jsp?ods key=nsf12602) accelerators are used to build entrepreneurial competencies and efficacy in teams of engineers and scientists with high technical competencies, with the objective of moving the I-Corp teams from the 'lost opportunity' cell to the 'aspirational' cell. I-Corp started in 2012, by 
bringing three-person teams typically consisting of a technical research academic who had been awarded NSF funding for research, a post-doc, and an entrepreneurial mentor to Stanford, University of Michigan or Georgia Tech to be intensely trained in Steve Blank's “Lean LaunchPad" together (Colao, 2012; Blank, 2013). Interestingly, the I-Corp accelerator process is designed to show STEM PhDs that they often do not know what they do not know in business by requiring I-Corp teams to "leave the building" and talk with potential customers about their problems and ideal solutions. After a day of working with I-Corp teams on customer development and engagement, Steve Blank remarked that while I-Corp "students may be brilliant white coats... in my world they do not know s---," (Colao quoting Steve Blank, 2012, p. 42). To bridge this gap, I-Corps now follows this entrepreneurial competencies self-assessment with remedial EE\&T interventions.

Figure 3

Relationship between entrepreneurial competencies and entrepreneurial self-efficacy ${ }^{1}$

\begin{tabular}{|c|c|c|}
\hline High & Lost opportunity & Aspiration \\
\hline \multicolumn{3}{|l|}{ Actual } \\
\hline \multirow[t]{2}{*}{ Low } & Inertia & Risky Action \\
\hline & Low & High \\
\hline 1: Adapted from $\mathrm{K}$ & \multicolumn{2}{|c|}{$\begin{array}{l}\text { Entrepreneurial } \\
\text { self-efficacy }\end{array}$} \\
\hline
\end{tabular}


Nascent entrepreneurs prior to participation in the accelerator often have a limited mastery of entrepreneurial competencies, but are highly self-confident and would likely be classified into the 'risky action' cell of Figure 3. Participating in the accelerator offers these nascent entrepreneurs the opportunity for self-assessment of their mastery of critical entrepreneurial competencies. From an EE\&T policy perspective, the opportunity for an authentic self-assessment by aspiring entrepreneurs may be the accelerator's raison d'être.

\section{Conclusion}

This preliminary study contributes to a closer alignment between EE\&T and the actual practice of entrepreneurship by exploring how accelerators can be useful as authentic learning platforms for the development of entrepreneurial competencies. Accelerators offer nascent entrepreneurs a potential avenue to overcome competency gaps in an immersive, authentic learning environment. However, these gaps may only be revealed entrepreneur after the self-assessment and reflection processes provided by the accelerator program. This insight contributes to EE\&T policy and practice.

The potential for accelerators to be supported by policy makers and practitioners as both an effective EE\&T program and a useful entrepreneurial ecosystem and economic development tool may be helpful in economic development policy debates at the local, regional and national levels. In addition, the present study contributes to EE\&T practice by explaining how the how accelerators build entrepreneurial competencies through linking the operating processes of accelerators and the nine elements of Herrington and Oliver's (2000) authentic learning framework. 
While these contributions are preliminary, the authors believe that this paper and its preliminary findings will stimulate additional work and replication in this area, preferably where a matched sample approach to data collection is not constrained. In addition, future studies could adopt measures to capture the act of reflection and its outcomes (e.g. Herrington et al., 2014). Likewise, future research could make use of the recently released European Commission's Entrepreneurship Competency Framework that has an objective to “bridge between the worlds of education and work, by contributing to a better understanding of entrepreneurship competence..." (Bacigalupo et al., 2016, p. 7). This framework offers items purporting to measure the respondent's competencies to (1) spot, create, value, and assess ideas and opportunities; (2) develop, harness and leverage human, organizational, social, and economic resources; and (3) plan, implement, manage and learn from entrepreneurial initiatives. Once psychometrically assessed and understood the framework could be matched with the nine elements of the authentic learning processes that occur within an accelerator.

The present study has limitations that constrain its generalizability. One limitation is that the items are self-reported, perceptual and may not measure the actual entrepreneurial competencies of the respondent. The second limitation is due to the need to obtain permission from the accelerator managers to administer the surveys to accelerator applicants and graduates. Thus, matched or paired sampling was not possible. In addition, the lack of statistically significant results from the t-tests may be due to limitations in the study's design, metrics, sampling, or theory. The findings and insights are preliminary and should be tested and refined in future studies.

However, by applying the nine elements of Herrington and Oliver's (2000) authentic learning framework to the operating processes of accelerators, the present study proposes a 
preliminary explanation for understanding how accelerators build entrepreneurial competencies. The accelerator process forces participants to bridge the gap between EE\&T and the practice of entrepreneurship and provides the opportunity to ameliorate a problem in entrepreneurship and business that Kruger and Dunning (1999) define as being "unskilled and unaware."

\section{References}

Amway (2016), 2016 Global Entrepreneurship Report, available at https://www.amway.com.au/en/my-business/business-material/global-entrepreneurshipreport-2016/, accessed 5 Jan 2017.

Ardichvili, A., Cardozo, R., and Ray, S. (2003), "A theory of entrepreneurial opportunity identification and development", Journal of Business Venturing, Vol. 18 No. 1, pp. 105123.

Bacigalupo, M., Kampylis, P., Punie, Y., and Van den Brande, G. (2016), EntreComp: The Entrepreneurship Competence Framework, Luxembourg: Publication Office of the European Union.

Balan, P., and Metcalfe, M. (2012), "Identifying teaching methods that engage entrepreneurship students", Education+ Training, Vol. 54 No. 5, pp. 368-384.

Balan, P., Clark, M., and Restall, G. (2015), "Preparing students for Flipped or Team-Based Learning methods", Education + Training, Vol. 57 No. 6, pp. 639-657.

Bergmann, J., and Sams, A. (2014), Flipped learning: Gateway to Student Engagement. USA: International Society for Technology in Education.

Blank, S. (2013), "Why the lean start-up changes everything", Harvard Business Review, Vol. 91 No. 5, pp. 63-72.

Bliemel, M. (2016), “Authentic Learning Experiences in Entrepreneurship: Engaging External Stakeholders. Australian Centre for Entrepreneurship Research Exchange", February 2-5, 2016; UNSW Business School Research Paper No. 2016MGMT02. Available at SSRN: https://ssrn.com/abstract=2826331.

Bliemel, M., Flores, R., De Klerk, S., and Miles, M.P. (2016), The role and performance of accelerators in the Australasian start-up ecosystem. Report for the Australian Department of Industry, Innovation \& Science, February, Canberra, Australian Capital Territory. https://ssrn.com/abstract_id=2826317.

Breuer, H. and Mahdjour, S. (2012), "Lean Venturing: Entrepreneurial learning to model and grow new business", In ISPIM Innovation Symposium- Stimulating Innovation: Challenges for Management, Science and Technology. The International Society for Professional Innovation Management, Seoul, Korea, 9-12 December, pp. 1-14. 
Christiansen, J. (2009), Copying Y Combinator, A framework for developing Seed Accelerator Programs. Unpublished Master's Thesis, Cambridge: The Judge Business School.

Cohen, S. (2013), How to accelerate learning: Entrepreneurial ventures participating in accelerator programs, Unpublished Doctoral Dissertation, Chapel Hill: University of North Carolina.

Cohen, S., and Bingham, C.B. (2013), "How to accelerate learning: Entrepreneurial ventures participating in accelerator programs", In Academy of Management Proceedings, Vol. 2013 No. 1, p. 14803. New York: Academy of Management.

Cohen, S., and Hochberg, Y.V. (2014), “Accelerating start-ups: The seed accelerator phenomenon", Available at SSRN 2418000.

Colao, J.J. (2012), “Get outta the lab!”, Forbes. Vol. 190 No. 3, pp. 42-44.

Davidsson, P. (2015), "Entrepreneurial opportunities and the entrepreneurship nexus: A reconceptualization”, Journal of Business Venturing, Vol. 30 No. 5, pp. 674-695.

Fayolle, A., Verzat, C., and Wapshott, R. (2016), "In quest of legitimacy: The theoretical and methodological foundations of entrepreneurship education research", International Small Business Journal, Vol. 34 No. 7, pp. 895-904.

Garud, R., Gehman, J., and Giuliani, A.P. (2014), "Contextualizing entrepreneurial innovation: A narrative perspective", Research Policy, Vol. 43 No. 7, pp. 1177-1188.

Gonzalez-Uribe, J., and Leatherbee, M. (2016), "The Effects of Business Accelerators on Venture Performance: Evidence from Start-up Chile (August 11)", Available at SSRN: http://ssrn.com/abstract=2651158.

Graham, P. (2012), How Y Combinator Started. Available at http://old.ycombinator.com/start.html, accessed 5 Jan 2017.

Hallen, B.L., Bingham, C., and Cohen, S. (2016), "Do Accelerators Accelerate? The Role of Indirect Learning in New Venture Development 2016". Available at SSRN: http://ssrn.com/abstract=2719810.

Hathaway, I. (2016), What start-up accelerators really do? Available at https://hbr.org/2016/03/what-start-up-accelerators-really-do, accessed May 23, 2016.

Hayward, M.L., Shepherd, D.A., and Griffin, D. (2006), "A hubris theory of entrepreneurship”, Management Science, Vol. 52 No. 2, pp. 160-172.

Herrington, J., and Oliver, R. (2000), "An instructional design framework for authentic learning environments", Educational Technology Research and Development, Vol. 48 No. 3, pp. 23-48.

Herrington, J., and Parker, J. (2013), "Emerging technologies as cognitive tools for authentic learning”, British Journal of Educational Technology, Vol. 44 No. 4, pp. 607-615.

Herrington, J., Parker, J., and Boase-Jelinek, D. (2014), “Connected authentic learning: Reflection and intentional learning", Australian Journal of Education, Vol. 58 No. 1, pp. 23-35. 
Hogarth, R.M., and Karelaia, N. (2012), "Entrepreneurial success and failure: Confidence and fallible judgment”, Organization Science, Vol. 23 No. 6, pp. 1733-1747.

Jones, C., and Matlay, H. (2011). "Understanding the heterogeneity of entrepreneurship education: going beyond Gartner”, Education+ Training, Vol. 53 No. 8/9, pp. 692-703.

Jones, C., Matlay, H., Penaluna, K., and Penaluna, A. (2014). "Claiming the future of enterprise education”, Education+ Training, Vol. 56 No. 8/9, pp. 764-775.

Kanbach, D.K., and Stubner, S. (2016). "Corporate accelerators as recent form Of start-up engagement: the what, the why, and the how", Journal of Applied Business Research, Vol. 32 No. 6, pp.1761-1776.

Kasouf, C., Morrish, S., and Miles, M.P. (2015), "The moderating role of explanatory style between experience and entrepreneurial self-efficacy", International Entrepreneurship and Management Journal, Vol. 11 No. 1, pp. 1-17.

Kassean, H., Vanevenhoven, J., Liguori, E., and Winkel, D.E. (2015), "Entrepreneurship education: a need for reflection, real-world experience and action", International Journal of Entrepreneurial Behavior \& Research, Vol. 21 No. 5, pp. 690-708.

Klein, P.G. (2008), “Opportunity discovery, entrepreneurial action, and economic organization”, Strategic Entrepreneurship Journal, Vol. 2 No. 3, pp. 175-190.

Kirzner, I.M. (2009), “The alert and creative entrepreneur: a clarification”, Small Business Economics, Vol. 32 No. 2, pp. 145-152.

Kolb, D.A. (1984). Experiential learning as the science of learning and development. Eaglewood Cliffs. Prentice Hall, New Jersey.

Kruger, J., and Dunning, D. (1999), "Unskilled and unaware of it: how difficulties in recognizing one's own incompetence lead to inflated self-assessments", Journal of Personality and Social Psychology, Vol. 77 No. 6, pp. 1121-1134.

Kyndt, E., and Baert, H. (2015), Entrepreneurial competencies: Assessment and predictive value for entrepreneurship. Journal of Vocational Behavior, Vol. 90, pp.13-25.

Lackéus, M., and Middleton, K.W. (2015), "Venture creation programs: bridging entrepreneurship education and technology transfer", Education+ Training, Vol. 57 No. 1, pp. 48-73.

Lans, T., Verstegen, J., and Mulder, M. (2011), “Analysing, pursuing and networking: Towards a validated three-factor framework for entrepreneurial competence from a small firm perspective", International Small Business Journal, Vol. 29 No. 6, pp. 695-713.

Lahn, L.C., and Erikson, T. (2016), "Entrepreneurship education by design”, Education+ Training, Vol. 58 No. 7/8, pp. 684-699.

Leppisaari, I., Herrington, J., Vainio, L., and Im, Y. (2013) “Authentic e-Learning in a multicultural context: Virtual benchmarking cases from five countries", Journal of Interactive Learning Research, Vol. 24 No. 1, pp. 53-73.

Macht, S.A., and Ball, S. (2016), "Authentic Alignment"-a new framework of entrepreneurship education”, Education + Training, Vol. 58 No. 9, pp. 926-944. 
Maritz, A., and Brown, C. (2013), "Enhancing entrepreneurial self-efficacy through vocational entrepreneurship education programmes", Journal of Vocational Education \& Training, Vol. 65 No. 4, pp. 543-559.

Matlay, H. (2001), "Entrepreneurial and vocational education and training in Central and Eastern Europe", Education + Training, Vol. 43 No. 8/9, pp. 395-404.

Matlay, H. (2006), "Researching entrepreneurship and education: Part 2: what is entrepreneurship education and does it matter?" Education + Training, Vol. 48 No. 8/9, pp. 704-718.

Mehlhorn, J.E., Bonney, L., Fraser, N., and Miles, M.P. (2015), "Benchmarking Entrepreneurship Education in the U.S. Australia, and New Zealand University Agriculture Programs", Journal of Developmental Entrepreneurship, Vol. 20 No. 3, DOI: http://dx.doi.org/10.1142/S108494671550017X.

Miles, M.P., Lewis, G.K., Hall-Phillips, A., Morrish, S.C., Gilmore, A., and Kasouf, C. (2016), "The influence of entrepreneurial marketing processes and entrepreneurial selfefficacy on community vulnerability, risk and resilience”, Journal of Strategic Marketing. Vol. 24 No. 1, pp. 34-46.

Miller, P., and Bound, K. (2011), The Start-up Factories: The rise of accelerator programmes to support new technology ventures, London: NESTA.

Morris, M.H., Webb, J. W., Fu, J., and Singhal, S. (2013), “A Competency-Based Perspective on Entrepreneurship Education: Conceptual and Empirical Insights”, Journal of Small Business Management, Vol. 51 No. 3, pp. 352-369.

Nambisan, S., and Baron, R.A. (2013), "Entrepreneurship in Innovation Ecosystems: Entrepreneurs' Self-Regulatory Processes and Their Implications for New Venture Success", Entrepreneurship Theory and Practice, Vol. 37 No. 5, pp. 1071-1097.

Nunnally, J.C. (1978), Psychometric Theory. $2^{\text {nd }}$ ed. New York: McGraw-Hill.

Pauwels, C., Clarysse, B., Wright, M., and Van Hove, J. (2016), "Understanding a new generation incubation model: The accelerator", Technovation, Vol. 50, pp. 13-24.

Piperopoulos, P., and Dimov, D. (2015), "Burst bubbles or build steam? Entrepreneurship education, entrepreneurial self-efficacy, and entrepreneurial intentions". Journal of Small Business Management, Vol. 53 No 4, pp. 970-985.

Podsakoff, P. M., and Organ, D. W. (1986), "Self-reports in organizational research: Problems and prospects", Journal of Management, Vol. 12 No. 4, pp. 531-544.

Roberts, P., Lall, S., Baird, R., Eastman, E., Davidson, A., and Jacobson, A. (2016), What's working in start-up acceleration: Insights from fifteen Village Capital programs. Atlanta: Emory University.

Robinson, S., Neergaard, H., Tanggaard, L., and Krueger, N.F. (2016), "New horizons in entrepreneurship education: from teacher-led to student-centered learning", Education+ Training, Vol. 58 No. 7/8, pp. 661-683. 
Sardeshmukh, S., and Corbett, A. (2011), "The Duality of Internal and External Development of Successors: Opportunity Recognition in Family Firms", Family Business Review, Vol. 24 No. 2, pp. $111-125$.

Scott, J.M., Penaluna, A., and Thompson, J.L. (2016), “A critical perspective on learning outcomes and the effectiveness of experiential approaches in entrepreneurship education: do we innovate or implement?" Education+ Training, Vol. 58 No. 1, pp. 82-93.

Shane, S. and Venkataraman, S. (2000), "The promise of entrepreneurship as a field of research", Academy of Management Review, Vol. 25 No. 1, pp. 217-226.

Shane, S. (2009), "Why encouraging more people to become entrepreneurs is bad public policy”, Small Business Economics, Vol. 33 No. 2, pp. 141-149.

Stevenson, H.H., and Gumpert, D.E. (1985), "The heart of entrepreneurship", Harvard Business Review, Vol. 63 No. 2, pp. 85-94.

TechCrunch (2015), "Accelerators are the new business school”, available at https://techcrunch.com/2015/07/11/accelerators-are-the-new-business-school/, accessed 5 Jan 2017.

The Economist. (2014), "Accelerators, getting up to speed: The biggest professional training system you have never heard of", The Economist, Vol 410 No. 8870, pp. 7-10.

Thongpravati, O., Maritz, A., and Stoddart, P. (2016), "Fostering Entrepreneurship and Innovation through a Biomedical Technology PhD Program in Australia", International Journal of Engineering Education, Vol. 32 No. 3, pp. 1222-1235.

Venkataraman, S. (1997), "The distinctive domain of entrepreneurship research", Advances in Entrepreneurship, Firm Emergence and Growth, Vol. 3 No. 1, pp. 119-138.

Wood, D., Bruner, J., and Ross, G. (1976), “The role of tutoring in problem solving”, Journal of Child Psychology and Psychiatry, Vol. 17 No. 2, pp. 89-100. 